\title{
Macrobenthic species response surfaces along estuarine gradients: prediction by logistic regression
}

\author{
Tom Ysebaert ${ }^{1,2, *}$, Patrick Meire $^{1, * *}$, Peter M. J. Herman ${ }^{2}$, Harmen Verbeek $^{3}$ \\ ${ }^{1}$ Institute of Nature Conservation, Kliniekstraat 25, 1070 Brussel, Belgium \\ ${ }^{2}$ Netherlands Institute of Ecology, Centre for Estuarine and Coastal Ecology, PO Box 140, 4400 AC Yerseke, The Netherlands \\ ${ }^{3}$ National Institute for Coastal and Marine Management/RIKZ, PO Box 8039, 4330 EA Middelburg, The Netherlands
}

\begin{abstract}
This study aims at contributing to the development of statistical models to predict macrobenthic species response to environmental conditions in estuarine ecosystems. Ecological response surfaces are derived for 10 estuarine macrobenthic species. Logistic regression is applied on a large data set, predicting the probability of occurrence of macrobenthic species in the Schelde estuary as a response to the predictor variables salinity, depth, current velocity and sediment characteristics. Single logistic regression provides good descriptions of the occurrence along 1 environmental variable. The response surfaces obtained by multiple logistic regression provide estimates of the probability of species occurrence across the spatial extent of the Schelde estuary with a relatively high degree of success. Results from subsampling $50 \%$ of the original data 10 times indicate that final models were stable. A visual geographical comparison is presented between the mapped probability surfaces and the species occurrence maps. We conclude that where patterns of distribution are strongly and directly coupled to physicochemical processes, as is the case at the estuarine macro- and meso-scale, our modelling approach was capable of predicting macrobenthic species distributions with a relatively high degree of success, although processes controlling estuarine macrobenthic distribution cannot be determined using this method. However, the models and predictions could be used for evaluation of the effects of different management schemes within the Schelde estuary.
\end{abstract}

KEY WORDS: Benthic macrofauna - Estuarine, spatial gradients - Logistic regression - Response surfaces $\cdot$ Schelde estuary

\section{INTRODUCTION}

Estuaries are transitional environments between rivers and the sea, and are characterised by widely varying and often unpredictable hydrological, morphological and chemical conditions (Day et al. 1989). For benthic animals with limited mobility (after settlement) this spatial and temporal variability represents a problem with which they have to cope.

A quantitative prediction of the patterns of occurrence of macrobenthic animals in estuaries is a desir-

\footnotetext{
*E-mail: ysebaert@cema.nioo.knaw.nl

${ }^{* *}$ Present address: University of Antwerp, Department Biology, Universiteitsplein 1, 2610 Wilrijk, Belgium
}

able goal for several reasons. Benthic-pelagic links in estuaries are in general very important (Herman et al. 1999). Understanding the dynamics of the estuarine system requires a quantitative insight into benthic processes, which may be responsible for up to half of the mineralisation of the total system (Heip et al. 1995, Herman et al. 1999). Macrobenthos has a pronounced structuring effect on the sediment properties and mineralisation processes (Rhoads 1974, Aller \& Aller 1998), and is an important food resource for epibenthic crustaceans, fishes and birds. Humans harvest many species of shellfish and crustaceans. Rational management of these resources requires predictive capabilities of the dynamics of the populations. 
Nowadays, macrobenthos is often used in monitoring programmes as a bioindicator for possible changes in the system. Within this ecological indicator system approach, a lot of studies have investigated the structure of macrobenthic communities in relation to the abiotic environment, coupling the dominance patterns (e.g. ABC method: Warwick 1986) or functional lifehistory characteristics (trophic structure: Pearson \& Rosenberg 1978, Boesch \& Rosenberg 1981, Gaston et al. 1998) of the macrobenthos to human impacts. But within coastal marine and estuarine ecosystems few attempts have been made to statistically model the responses of individual macrobenthic species to environmental variables on a large, e.g. estuarine, scale and to use these models to predict the distribution and occurrence of macrobenthos (Constable 1999). However, there are increasing demands for reliable and quantitative predictive tools. On the one hand, these are required to interpret post hoc any changes that have been observed in the benthic community: a quantification of species preferences and tolerances to environmental conditions may help to understand and establish system properties. On the other hand, they are needed to predict future species response to anticipated changes in environmental conditions.

The aim of this study was to contribute to the development of statistical models to predict macrobenthic species response to environmental conditions in estuarine ecosystems. In this paper, so-called response curves and surfaces are fitted through mathematical relations (Swan 1970, Austin 1987) obtained by logistic regression. The advantage of logistic regression is that the probability of occurrence of an event can be predicted as a function of 1 or more independent variables (Hosmer \& Lemeshow 1989, Trexler \& Travis 1993). Logistic regression has been applied in many ecological studies, e.g. in vegetation analysis (Huisman et al. 1993, Lenihan 1993, van de Rijt et al. 1996) and bird and wildlife species distributions (Osborne \& Tigar 1992, Buckland \& Elston 1993, Venier et al. 1999). In the field of marine and estuarine animal ecology, this technique has rarely been used.

Our approach uses physicochemical factors, acting at different spatial scales, as predictors for the occurrence of several macrobenthic species. The realised environmental niches of estuarine macrobenthic species are thus defined and validated. This paper presents a first step in predicting the spatial distribution of macrobenthic populations. The next step will be to extend the models towards prediction of patterns in abundance and biomass and to investigate the possibility of using the models for evaluation of the effects of different management schemes and to investigate the applicability of the models in other estuarine systems.

\section{MATERIALS AND METHODS}

Study area. The Schelde estuary, a turbid, nutrientrich, heterotrophic system, measures $160 \mathrm{~km}$ from the mouth near Vlissingen (The Netherlands) to Ghent (Belgium), and is one of the longest estuaries in NW Europe with a still complete salinity gradient. The study area is limited to the Westerschelde (Dutch part) and a small part of the Zeeschelde (Belgian part) near the Dutch-Belgian border (Fig. 1), comprising the complete polyhaline and mesohaline zone of the estuary. The mean tidal range increases from $3.8 \mathrm{~m}$ at Vlissingen to $5.0 \mathrm{~m}$ near the border. The river discharge varies from $20 \mathrm{~m}^{3} \mathrm{~s}^{-1}$ during summer to $600 \mathrm{~m}^{3} \mathrm{~s}^{-1}$ during winter, with a mean yearly average of $105 \mathrm{~m}^{3} \mathrm{~s}^{-1}$ (Baeyens et al. 1998). The residence time of the water in the estuary is rather high, ranging from 1 to $3 \mathrm{mo}$, depending on the river discharge (Soetaert \& Herman 1995). The most seaward region has a residence time of about 10 to $15 \mathrm{~d}$.

The lower and middle estuary, called the Westerschelde $(55 \mathrm{~km})$, is a well-mixed region characterised by a complex morphology with flood and ebb channels surrounding several large intertidal flats and salt marshes. The surface of the Westerschelde amounts to $310 \mathrm{~km}^{2}$, with the intertidal area covering $35 \%$. The average channel depth is approximately 15 to $20 \mathrm{~m}$. In the lower and middle estuary a multiple channel equilibrium exists, while upstream of the Dutch/Belgian border the estuary is characterised by a single channel. The turbidity maximum is situated in this region of the estuary but moves over a quite large distance, depending among other factors on tidal action and river run-off (Baeyens et al. 1998). Nowadays, dredging activities for shipping as well as pollution are the major anthropogenic stressors. About 8 to 12 million $\mathrm{m}^{3}$ of sediment is dredged yearly to keep the port of Antwerpen accessible. For more details on the ecological and physicochemical properties of the estuary see Meire \& Vincx (1993), Heip \& Herman (1995), Baeyens et al. (1998), Herman \& Heip (1999) and van Damme et al. (unpubl. data).

Macrobenthos data. An extensive data set on macrobenthos is available for the Schelde estuary. A total of 3112 macrobenthos samples, mainly within the framework of monitoring programmes, were collected in the study area by different institutes in the period 1978 to 1997, but with $>90 \%$ of the samples collected from 1990 onwards. Qualitatively, no fundamental nor systematic changes in the occurrence of the macrobenthos appeared in the study area. The use of such a large, long-term data set allows us to be more certain of a species being present in a certain environment and to compensate for accidental observations.

By far most of the data were collected and analysed by 2 institutes: the Centre for Estuarine and Coastal 
Ecology NIOO-CEMO (e.g. Craeymeersch et al. 1996, Brummelhuis et al. 1997, Craeymeersch 1999), and the Institute of Nature Conservation (e.g. Ysebaert \& Meire 1991, Ysebaert 2000, Ysebaert et al. 2000), mainly in co-operation with the National Institute for Marine and Coastal Management (RWS-RIKZ); $54 \%$ were taken in autumn (September and October), 32\% in spring (March, April, May). Most sampling locations $(68 \%)$ were sampled only once, but several locations were sampled 2 to 5 times during the sampling period considered, and a few were sampled more frequently within a long-term programme.

In general, multiple sediment cores were used for sampling the intertidal zone, and either a van Veen grab or a Reineck box corer for the subtidal zone. In the intertidal zone most samples $(77 \%)$ had a sample size between 0.015 and $0.023 \mathrm{~m}^{2}$, while another $18 \%$ had a sample size of $0.01 \mathrm{~m}^{2}$. In the subtidal zone, most samples $(76 \%)$ had a sample size of approximately $0.015 \mathrm{~m}^{2}$, which is comparable to the sample size of the samples in the intertidal zone. A minor percentage of the subtidal samples were much larger $(0.10$ to $0.12 \mathrm{~m}^{2}$ ). As difference in sample size was rather small between most samples, the effect of sample size on the occurrence of a certain species is expected to be small.

All samples were sieved through $1 \mathrm{~mm}$ mesh. For more details on the sampling methods and the design of the monitoring programmes see Meire et al. (1991), Ysebaert et al. (1993) and Craeymeersch (1999).

Abiotic variables. For each sample the following abiotic environmental variables were added to the macrobenthos database: depth/elevation, salinity, current velocities (maximum ebb- and flood-current velocities), sediment characteristics (median grain size and mud content). At subtidal stations depth was recorded at the time of sampling. The elevation of the intertidal stations was measured directly in the field or derived from the RIKZ Geographical Information System, storing all bathymetric data in the area. For 2874 samples $(92 \%)$, depth was added in the database. Depth is expressed in m NAP (NAP = Dutch Ordnance level, similar to 'mean sea level').

Salinity was estimated for each sampling location using a 2Dh-hydrodynamic model SCALDIS400 (Lievense 1994) with a spatial resolution of $400 \mathrm{~m}$. The

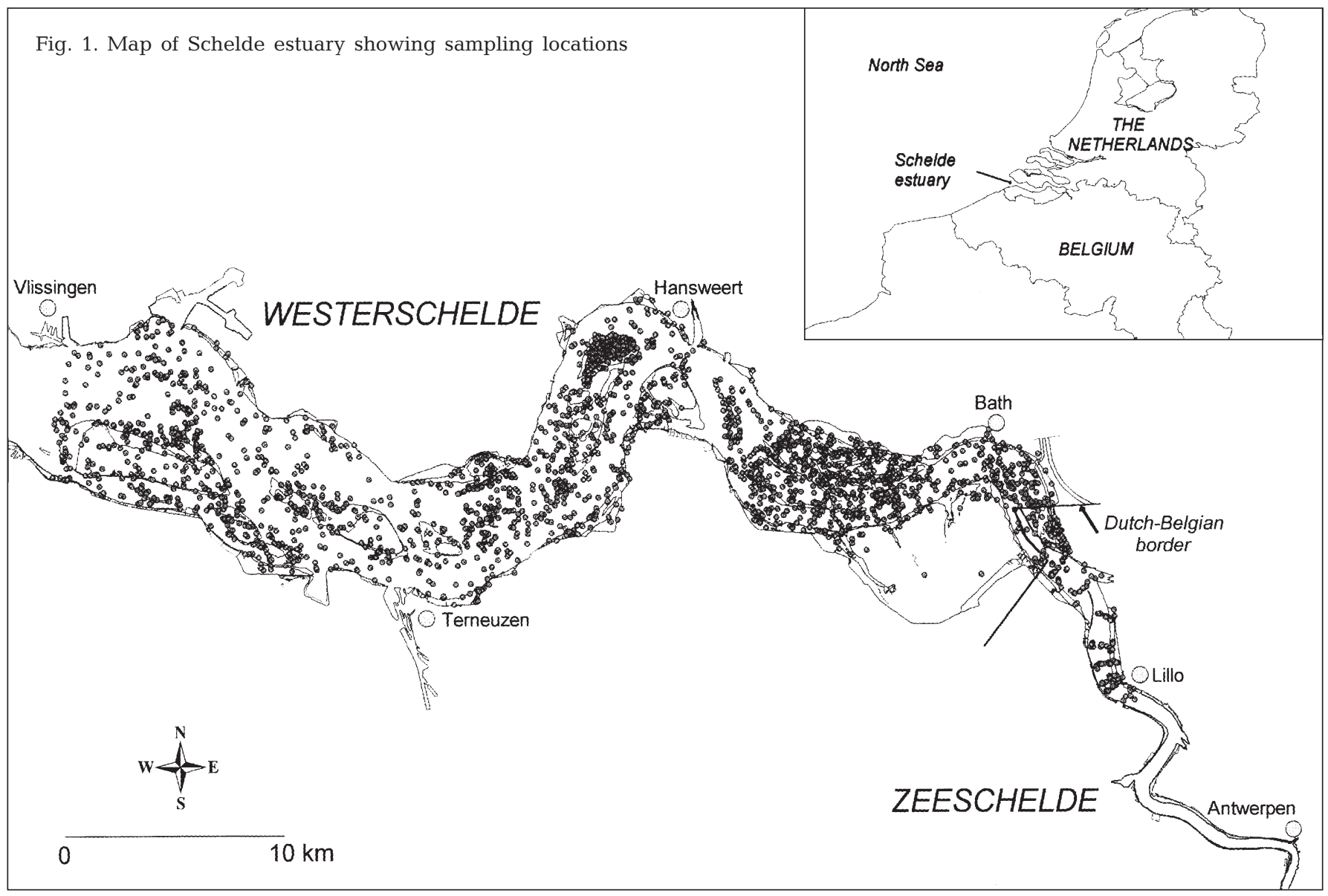


model calculations are based on values for mean tidal conditions with a yearly averaged discharge, giving an average salinity value. The advantage of using the SCALDIS400 model is that a high spatial resolution is obtained but the estimates are not seasonally defined. Therefore, also monthly to fortnightly measurements at 9 stations along the Westerschelde were used to represent the temporal variation in salinity, but at a much coarser spatial resolution than model salinity. For each sample, the temporal salinity was determined as the average salinity of the 3 mo prior to the date of sampling. Estimates obtained from model simulations are called 'model salinities', whereas the values derived from field observations are called 'temporal salinities'.

Current velocities (maximum ebb- and flood-current velocities in $\mathrm{m} \mathrm{s}^{-1}$ ) for each sampling location were estimated with the SCALDIS100 model (Dekker et al. 1994) for mean tidal conditions, with a spatial resolution of $100 \mathrm{~m}$. For 3037 samples (98\%), current velocity estimates were added to the database.

Samples for sediment grain-size analysis (by the laser diffraction technique) were collected during several field campaigns. For 1502 and 1386 samples (48 and $45 \%$ ), median grain size and mud content (vol\% $<63 \mu \mathrm{m}$ ) values were added to the database respectively.

Statistical analysis. Logistic regression (Cox 1970, Hosmer \& Lemeshow 1989, Trexler \& Travis 1993, Jongman et al. 1995) falls within the general framework of generalized linear models (GLM) (Nelder \& Wedderburn 1972, McCullagh \& Nelder 1989) and can be used to analyse the relationship between a binary response variable and 1 or more explanatory variables. Logistic regression is used here to model the response of the occurrence of 20 macrobenthic species to the abiotic environmental predictors. The choice of using binary (presence/absence) data was inspired by the fact that the data could not be considered as homogeneously collected. Especially seasonality (difference in sampling months) and, to a lesser extent, long-term fluctuations and the use of different sampling methods and sample sizes certainly affected the observed variation in density and biomass data. To minimise this variation, presence-absence data were used. Indeed, the presence-absence of most macrobenthic species appeared to be much less seasonally differentiated than density and biomass (Ysebaert 2000). As many species were often found accidentally, we decided to treat densities of $<50$ ind. $\mathrm{m}^{-2}$ as absences (0) for most species (except for Nephtys cirrosa and Arenicola marina).

In the logistic regression model, a binary response variable is related to 1 or more predictor variables through the logistic link function:

$$
\operatorname{logit}\{p(x)\}=\log \{p(x) / 1-p(x)\}=b_{0}+b_{1} x+b_{2} x^{2}
$$

where $p(x)$ is the probability that the species occurs as a function of an environmental variable $x$, and $b_{0}, b_{1}, b_{2}$ are the regression parameters. Eq. (1) can be rewritten to define the estimated probability $\mathrm{p}(x)$ as

$$
\mathrm{p}(\mathrm{x})=\left\{\mathrm{e}^{\left(\mathrm{b}_{0}+\mathrm{b}_{1} x+\mathrm{b}_{2} \mathrm{x}^{2}\right)}\right\} /\left\{1+\mathrm{e}^{\left(\mathrm{b}_{0}+\mathrm{b}_{1} x+\mathrm{b}_{2} \mathrm{x}^{2}\right)}\right\}
$$

which is bound between 0 and 1 .

The logistic link means that the probability of a species occurring is a logistic, s-shaped function when the linear predictor is a first-order polynomial, but for higher polynomials the predicted probability function will be more complex. For second-order polynomials it will approximate a bell-shaped function (Gaussian logit curve), which is an ecologically realistic response (ter Braak and Loonman 1986). Although skewed and more complex response curves can theoretically occur, they cannot be fitted with the GLM approach (see e.g. Bio et al. 1998). In this study, a response surface for each macrobenthic species on each of the independent variables was generated by logistic regression with the statistical package SAS (SAS Institute Inc. 1989). The regression parameters were estimated using the maximum likelihood method, assuming binomially distributed errors. The global model significance, as well as the significance of the different regression parameters, was tested using the $2 \ln L$ statistic based on the $\chi^{2}$-test ( $\mathrm{p}<0.05)$, where $L$ is the maximized likelihood. Besides response curves for each single abiotic variable separately, all variables were simultaneously used in a stepwise multiple logistic-regression analysis to derive a multivariate model that would predict the presence or absence of macrobenthic species. Negative depth values, ranging from -56.4 to $+2.2 \mathrm{~m}$, were replaced by positive values by changing sign (value $\times-1$ ) and adding $2.5 \mathrm{~m}$. Since sediment characteristics were only available for a limited set of data, the analyses were run separately without $(\mathrm{n}=2827)$ and with $(\mathrm{n}=1423)$ sediment data, hereafter called Data Sets A and B respectively. The significance of the independent variables was tested using the $\chi^{2}$-test $(p<0.05)$ on the Wald statistic.

The resulting set of regression equations was validated internally. As a measure of classification accuracy, the percentage of concordant pairs was used (a pair is concordant if the observation with the largerordered value of the response has a higher predicted event probability than does the observation with the smaller-ordered value of the response). The predictive success of the response surfaces was further evaluated by cross-tabulating observed and predicted responses $(2 \times 2$ contingency table). The threshold at which this evaluation was made was determined by choosing that p-level which corresponded with the actually observed ratio between absences and presences. At p-values below that threshold the species was predicted to be 
absent, whereas at p-values above that threshold the species was predicted to be present. Besides the overall percentage of correct predictions, we also examined the sensitivity (the proportion of actual presences that were correctly predicted) and specificity (the proportion of actual absences that were correctly predicted). The probability of the observed contingency table occurring by random chance, given the row and column totals, was calculated with Fisher's exact test, which consists of calculating the actual probability of the observed $2 \times 2$ contingency table with respect to all other possible $2 \times 2$ contingency tables with the same column and row totals. The hypothesis was tested if the proportion of presences predicted as present was greater than the proportion of absences predicted as present.

The ability of the final models to predict the probability of occurrence was evaluated by randomly splitting the data (from Data Set A) into 2 equal groups, building the model with the chosen variables using half of the data. We conducted 10 such runs with 10 different splits of the data on each species. Firstly, we tested these 10 model runs, based on the random selections of $50 \%$ of the data, for consistency of their prediction. For each species model we generated random sets of abiotic conditions by generating 1000 uniformly distributed random numbers. For each species, ranges for the environmental variables were chosen relative to their observed distribution. For example, for the cockle Cerastoderma edule, numbers varied in the ranges $10-30,7-33,0-20,0-1$ and $0-1.1$ for model salinity, temporal salinity, depth, maximum ebb and maximum flood-current velocity respectively. Temporal salinity was randomly chosen in a range of \pm 3 of model salinity, and maximum flood-current velocity likewise was selected in the range of $\pm 0.1 \mathrm{~m} \mathrm{~s}^{-1}$ of maximum ebb-current velocity. We then generated predicted p-values for the 10 models, which were compared mutually. Secondly, we tested the predictions with the other half of the data sets by examining the overall percentage correctly predicted, the sensitivity and specificity for each of the 10 data sets. This procedure examines the ability of the model to predict the occurrence of the species for locations that are not included in the model and is therefore a more rigorous test of classification accuracy.

For 10 contrasting macrobenthic species, results are presented in detail: the polychaetes Heteromastus filiformis, Pygospio elegans, Nephtys cirrosa, Nereis diversicolor, Spio sp. and Arenicola marina, the molluscs (bivalves) Macoma balthica and Cerastoderma edule, and the crustaceans (amphipods) Bathyporeia sp. and Coro- phium volutator. These species represent different types of distribution and are indicator species for the macrobenthic assemblages found in the Schelde estuary, contributing substantially to the total density and biomass observed (Ysebaert et al. 1993, 1998, Ysebaert \& Meire 1999, Ysebaert 2000).

For Macoma balthica, Cerastoderma edule, Nephtys cirrosa and Corophium volutator a visual geographical comparison between the mapped probability surfaces and the species occurrence maps is also presented.

\section{RESULTS}

\section{Characterization of the abiotic environment}

Average model salinity, based on model calculations, varied between 5.7 and 31.6 for the whole study area (Table 1). Most samples (60\%) were situated in the polyhaline zone (salinity $>18$ ), $31 \%$ in the $\alpha$-mesohaline zone (salinity 10 to 18 ) and $15 \%$ in the $\beta$-mesohaline zone (salinity 5 to 10 ). Depth ranged between -56.4 and $+2.2 \mathrm{~m}$ NAP. About $50 \%$ of the sampling took place in the intertidal zone (above $-2 \mathrm{~m}$ NAP). Most of the subtidal samples $(68 \%)$ were situated above -10 m NAP. Maximum ebb- and flood-current velocities varied between 0.01 and $1.64 \mathrm{~m} \mathrm{~s}^{-1}$, with a mean of $0.64 \mathrm{~m} \mathrm{~s}^{-1} ; 11 \%$ of the samples had current velocities $<0.25 \mathrm{~m} \mathrm{~s}^{-1}, 27 \%$ between 0.25 and $0.5 \mathrm{~m}$ $\mathrm{s}^{-1}, 24 \%$ between 0.50 to $0.75 \mathrm{~m} \mathrm{~s}^{-1}, 22 \%$ between 0.75 and $1.00 \mathrm{~m} \mathrm{~s}^{-1}$ and $16 \%>1.00 \mathrm{~m} \mathrm{~s}^{-1}$. Median grain size varied between 16 and $664 \mu \mathrm{m}$, with a mean of $165 \mu \mathrm{m}$. Mud content varied between 0 and $95 \%$, with a mean of $19 \% ; 13 \%$ of the samples were characterised as muddy (median grain size in the range 2 to $63 \mu \mathrm{m}$ ), $19 \%$ as very fine sand (63 to $125 \mu \mathrm{m}), 54 \%$ as fine sand (125 to $250 \mu \mathrm{m}$ ) and $15 \%$ as medium sand ( 250 to $500 \mu \mathrm{m}$ ). More details on the abiotic environment of the same data set as used in this paper can be found in Ysebaert \& Meire (1999) and Ysebaert (2000).

Table 1. Environmental variables with numbers of observations (n), median, minimum and maximum values. NAP: Dutch Ordnance level

\begin{tabular}{|lccccc|}
\hline Variable & & $\mathrm{n}$ & Median & Min. & Max. \\
\hline Model salinity & $(\mathrm{psu})$ & 3112 & 22.3 & 5.69 & 31.61 \\
Temporal salinity & $(\mathrm{psu})$ & 3112 & 19.1 & 1.15 & 32.39 \\
Depth & $(\mathrm{NAP})$ & 2874 & -2.9 & -56.4 & +2.2 \\
Maximum ebb-current velocity & $\left(\mathrm{m} \mathrm{s}^{-1)}\right.$ & 3037 & 0.60 & 0.01 & 1.64 \\
Maximum flood-current velocity & $\left(\mathrm{m} \mathrm{s}^{-1)}\right.$ & 3037 & 0.64 & 0.01 & 1.61 \\
Median grain size & $(\mu \mathrm{m})$ & 1502 & 162 & 16 & 664 \\
Mud content $(<63 \mu \mathrm{m})$ & $(\%)$ & 1386 & 7.0 & 0 & 95.45 \\
\hline
\end{tabular}




\section{Observed distributions of macrobenthic species along environmental variables}

Fig. 2 presents the observed distribution of 10 macrobenthic species along the environmental variables salinity, depth, maximum ebb-current velocity and median grain size as box-and-whisker plots. Characteristic polyhaline species, such as Arenicola marina, Cerastoderma edule, Nephtys cirrosa and Spio sp. were clearly distinguished from mesohaline species such as Corophium volutator and Nereis diversicolor, although the latter had a very wide range of occurrence. Species like Bathyporeia sp., Heteromastus filiformis, Macoma balthica and Pygospio elegans took intermediate positions. With respect to depth, most species were observed mainly in the intertidal zone. Only N. cirrosa and Spio sp. were typically subtidal species, and Bathyporeia sp. and $H$. filiformis appeared to be present both in the intertidal and the subtidal zones.

Most species had a median of occurrence between 0.3 and $0.5 \mathrm{~m} \mathrm{~s}^{-1}$ for maximum ebb-current velocity, with lowest values observed for Corophium volutator
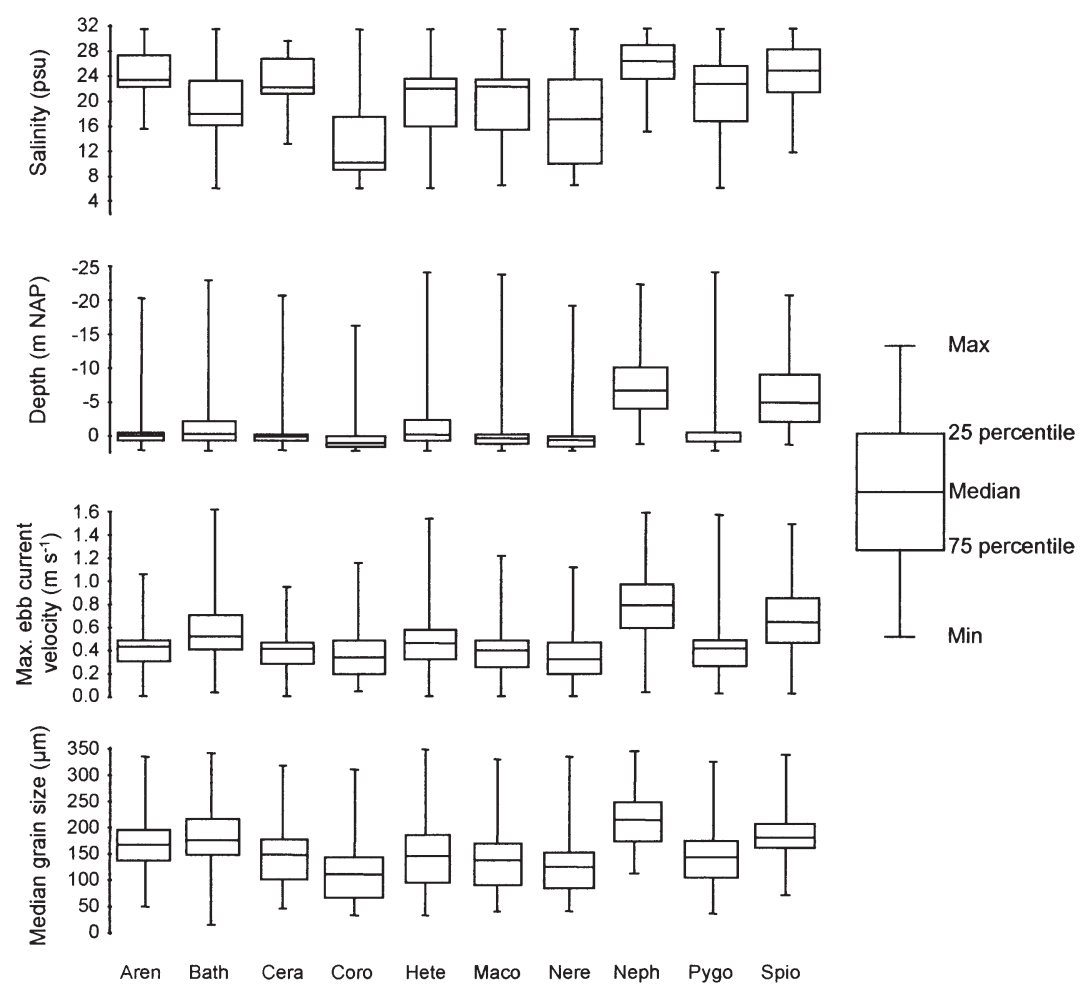

Fig. 2. Box-and-whisker plots for 10 macrobenthic species with respect to (model) salinity, depth, maximum ebb-current velocity and median grain size in the Schelde estuary. Species are ordered alphabetically. Aren: Arenicola marina; Bath: Bathyporeia sp.; Cera: Cerastoderma edule; Coro: Corophium volutator; Hete: Heteromastus filiformis; Maco: Macoma balthica; Nere: Nereis diversicolor; Neph: Nephtys cirrosa; Pygo: Pygospio elegans; Spio: Spio sp. and Nereis diversicolor. Only Nephtys cirrosa and Spio sp. had a median occurrence at much higher current velocities. For maximum flood-current velocity similar results were obtained. C. volutator and $N$. diversicolor were observed mainly in very fine sand sediments, whereas Spio sp. and especially $N$. cirrosa were observed in coarser sediments.

\section{Response curves for a single environmental (explanatory) variable}

As an example of the obtained response curves for a single abiotic variable, Figs 3 to 6 show the fitted Gaussian logit curves for the 10 macrobenthic species in relation to model salinity, depth, maximum ebbcurrent velocity and median grain size. For all species, at least 1 regression parameter was significantly entered in the different models by forward selection. The obtained response curves were in general agreement with the observed distributions from Fig. 2.

Species such as Corophium volutator and, to a lesser extent, Nereis diversicolor, showed a high probability of occurrence at low salinity (Fig. 3). For $C$. volutator, a steep decrease in the curve was observed with increasing salinity, whereas for $N$. diversicolor the decrease in the curve was much smoother, indicating that this species could also occur at higher salinity. Bathyporeia sp. showed a bell-shaped curve with an optimum at intermediate salinities; the probability of occurrence of this species decreased both at the lower end and at the upper end of the salinity range. Several species, such as Cerastoderma edule, N. cirrosa, Spio sp. and Arenicola marina, showed a clear optimum towards the higher end of the salinity range. These species differed in the position of their optimum, and in their tolerance towards the lower end of the salinity range. Macoma balthica had an almost horizontal curve, indicating a very broad tolerance for salinity. Another species showing a broad tolerance for salinity was Heteromastus filiformis. In general results for 'temporal salinity' were similar to those for results as 'spatial salinity'.

For most macrobenthic species (e.g. Pygospio elegans, Cerastoderma edule, Nereis diversicolor, Corophium volutator) the response curves in relation to 


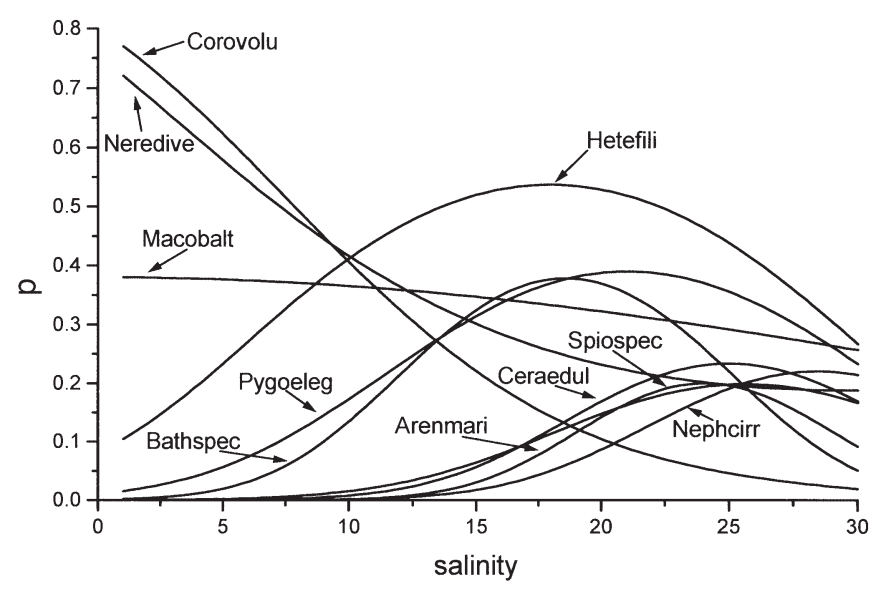

Fig. 3. Probability of occurrence (p) of 10 macrobenthic species in relation to (model) salinity (psu) in the Schelde estuary, fitted with logistic regression. Hetefili: Heteromastus filiformis; Macobalt: Macoma balthica; Pygoeleg: Pygospio elegans; Bathspec: Bathyporeia sp.; Ceraedul: Cerastoderma edule; Nephcirr: Nephtys cirrosa; Neredive: Nereis diversicolor; Corovolu: Corophium volutator; Spiospec: Spio sp.; Arenmari: Arenicola marina

depth were similar, with high probabilities of occurrence above NAP, and decreasing probabilities of occurrence with increasing depth (Fig. 4). These species differed in their tolerance towards the deeper end of the depth range. Heteromastus filiformis, for instance, showed a relatively high tolerance, with a still relatively high probability of occurrence in the subtidal zone. Bathyporeia sp. showed only a slightly higher probability of occurrence in the intertidal zone, indicating a very broad depth tolerance. Species showing an optimum in the subtidal zone of the estuary were Nephtys cirrosa and Spio sp.

Species such as Nereis diversicolor and Corophium volutator displayed the highest probability of occurrence at the lowest ebb-current velocities (Fig. 5). Other species such as Macoma balthica and Pygospio elegans showed a broad tolerance in the range 0 to $0.5 \mathrm{~m} \mathrm{~s}^{-1}$, after which a steep decline was observed in the probability of occurrence with increasing current velocities. This broad tolerance was even more pronounced for Heteromastus filiformis, which showed a decrease in probability of occurrence only at the highest current velocities. Bathyporeia sp. on the other hand displayed an almost horizontal curve, indicating that current velocity did not discriminate well for this species. Several species showed a unimodal, bellshaped curve with a clear optimum (e.g. Cerastoderma edule, Arenicola marina). Nephtys cirrosa was the only species showing an optimum towards the higher end of the current velocity range. Similar results were obtained for maximum flood-current velocity.

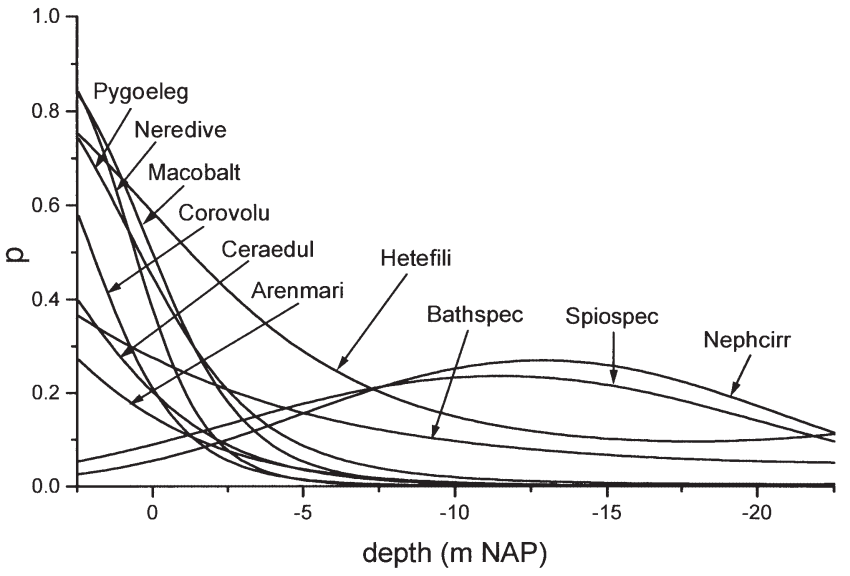

Fig. 4. Probability of occurrence (p) of 10 macrobenthic species in relation to depth (m NAP $=$ Dutch Ordnance level) in the Schelde estuary, fitted with logistic regression. Species abbreviations as in Fig. 3

The response curves in relation to median grain size clearly revealed different responses for the different macrobenthic species (Fig. 6). Nereis diversicolor showed the highest probability of occurrence in very muddy sediments with a low median grain size, with a steep decrease in the probability of occurrence with increasing median grain size. The same pattern was observed for Corophium volutator, but showing a broader tolerance. This tolerance was even more pronounced for Heteromastus filiformis and Macoma balthica. Pygospio elegans and Cerastoderma edule showed a bell-shaped curve with an optimum between 100 and $150 \mu \mathrm{m}$. This optimum shifted more towards a higher median grain size for Arenicola marina (approx. $155 \mu \mathrm{m})$, Spio sp. (approx. $200 \mu \mathrm{m}$ ) and Bathyporeia sp.

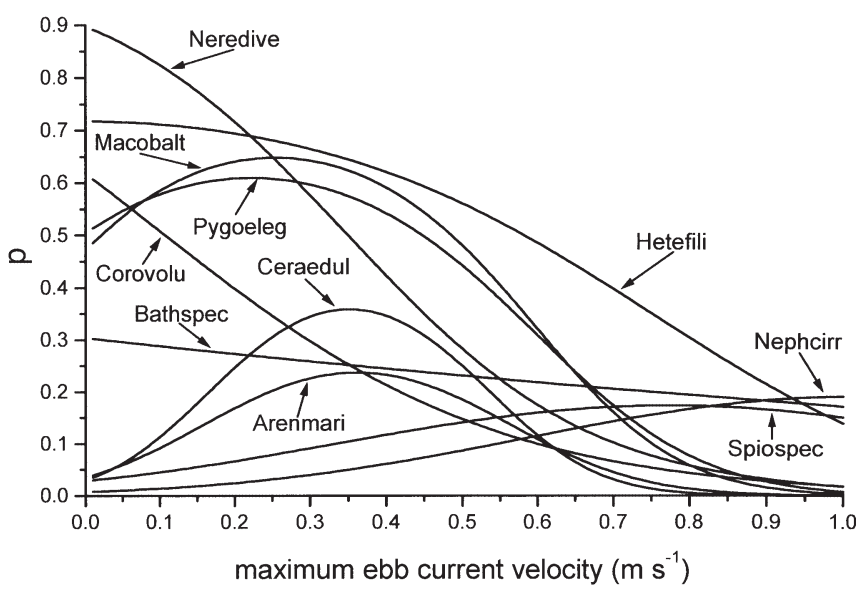

Fig. 5. Probability of occurrence (p) of 10 macrobenthic species in relation to maximum ebb-current velocity in the Schelde estuary, fitted with logistic regression. Species abbreviations as in Fig. 3 


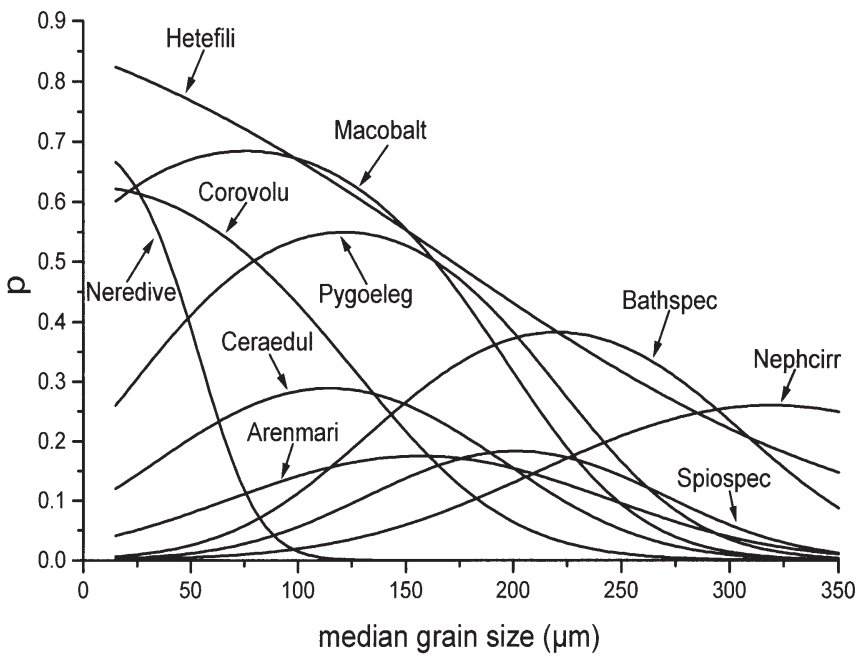

Fig. 6. Probability of occurrence (p) of 10 macrobenthic species in relation to median grain size in the Schelde estuary, as fitted with logistic regression. Species abbreviations as in Fig. 3 (approx. $225 \mu \mathrm{m}$ ). Nephtys cirrosa showed an optimum towards the higher end of the median grain size range.

\section{Multiple logistic regression}

For each macrobenthic species, a multiple stepwise logistic regression was run with all abiotic variables together. Since sediment characteristics were only available for a limited set of data, the analysis was run separately with and without sediment data.

Appendix 1 indicates the order in which the environmental variables were entered into the stepwise selection models. In all models, salinity (either model salinity, temporal salinity or both), depth, current velocity and sediment characteristics (for the models based on Data Set B) were entered into the models. Only for Macoma balthica was salinity not entered in the model based on Data Set A, which corresponds with the univariate model for salinity in which $M$. balthica showed a large tolerance.

Table 2. Diagnostics for final multiple logistic regression models for each of 10 macrobenthic species for data set without sediment data (Data Set A) and data set with sediment data (Data Set B). See Appendix 1 for variables included in each model. Species abbreviations as in Fig. 3

\begin{tabular}{|c|c|c|c|c|c|c|c|c|c|c|}
\hline Diagnostics & Hetefili & Macobalt & Pygoeleg & Bathspec & Ceraedul & Nephcirr & Neredive & Corovolu & Spiospec & Arenmari \\
\hline \multicolumn{11}{|l|}{ Data Set A } \\
\hline No. present & 1164 & 820 & 773 & 583 & 352 & 339 & 660 & 394 & 304 & 269 \\
\hline No. absent & 1663 & 2007 & 2054 & 2244 & 2475 & 2488 & 2167 & 2433 & 2523 & 2558 \\
\hline Intercept only $(-2 \ln L)$ & 3831 & 3405 & 3317 & 2877 & 2125 & 2074 & 3072 & 2283 & 1930 & 1777 \\
\hline $\begin{array}{l}\text { Intercept + covariates } \\
(-2 \ln L)\end{array}$ & 2897 & 1915 & 1965 & 2356 & 1176 & 1623 & 1581 & 1210 & 1485 & 1214 \\
\hline Chi-square & 952 & 1490 & 1352 & 521 & 949 & 451 & 1491 & 1074 & 445 & 563 \\
\hline $\mathrm{df}$ & 8 & 6 & 7 & 7 & 9 & 6 & 6 & 5 & 6 & 8 \\
\hline Probability & 0.0001 & 0.0001 & 0.0001 & 0.0001 & 0.0001 & 0.0001 & 0.0001 & 0.0001 & 0.0001 & 0.0001 \\
\hline Concordant pairs & $92.9 \%$ & $91.1 \%$ & $90.3 \%$ & $79.1 \%$ & $93.0 \%$ & $82.2 \%$ & $82.3 \%$ & $92.5 \%$ & $83.6 \%$ & $88.8 \%$ \\
\hline p-threshold & 0.51 & 0.61 & 0.50 & 0.38 & 0.42 & 0.32 & 0.47 & 0.33 & 0.29 & 0.35 \\
\hline$\%$ correctly predicted & $75.2 \%$ & $85.5 \%$ & $85.6 \%$ & $78.1 \%$ & $90.0 \%$ & $84.0 \%$ & $88.3 \%$ & $90.2 \%$ & $87.8 \%$ & $89.5 \%$ \\
\hline Sensitivity & $69.9 \%$ & $75.0 \%$ & $75.7 \%$ & $46.8 \%$ & $59.9 \%$ & $33.3 \%$ & $75.0 \%$ & $64.7 \%$ & $43.1 \%$ & $44.6 \%$ \\
\hline Specificity & $80.0 \%$ & $89.8 \%$ & $90.8 \%$ & $86.2 \%$ & $94.3 \%$ & $90.9 \%$ & $92.4 \%$ & $94.3 \%$ & $93.1 \%$ & $94.2 \%$ \\
\hline $\begin{array}{l}\text { Fisher exact test: } \\
1 \text {-tailed } \mathrm{p}\end{array}$ & 0.0001 & 0.0001 & 0.0001 & 0.0001 & 0.0001 & 0.0001 & 0.0001 & 0.0001 & 0.0001 & 0.0001 \\
\hline \multicolumn{11}{|l|}{ Data Set B } \\
\hline No. present & 686 & 562 & 492 & 331 & 232 & 102 & 454 & 313 & 169 & 172 \\
\hline No. absent & 607 & 731 & 910 & 962 & 1061 & 1191 & 839 & 1089 & 1124 & 1121 \\
\hline Intercept only $(-2 \ln L)$ & 1788 & 1770 & 1817 & 1471 & 1217 & 714 & 1676 & 1489 & 1003 & 1014 \\
\hline $\begin{array}{l}\text { Intercept + covariates } \\
(-2 \ln L)\end{array}$ & 1091 & 770 & 990 & 1044 & 679 & 449 & 896 & 750 & 604 & 620 \\
\hline Chi-square & 696 & 1000 & 827 & 427 & 538 & 264 & 780 & 739 & 399 & 394 \\
\hline df & 12 & 8 & 7 & 7 & 7 & 6 & 8 & 5 & 8 & 8 \\
\hline Probability & 0.0001 & 0.0001 & 0.0001 & 0.0001 & 0.0001 & 0.0001 & 0.0001 & 0.0001 & 0.0001 & 0.0001 \\
\hline Concordant pairs & $89.2 \%$ & $91.7 \%$ & $91.5 \%$ & $85.3 \%$ & $92.0 \%$ & $91.1 \%$ & $94.0 \%$ & $92.7 \%$ & $91.0 \%$ & $90.8 \%$ \\
\hline p-threshold & 0.56 & 0.61 & 0.35 & 0.46 & 0.42 & 0.19 & 0.50 & 0.36 & 0.42 & 0.36 \\
\hline$\%$ correctly predicted & $81.4 \%$ & $87.3 \%$ & $79.7 \%$ & $80.8 \%$ & $87.5 \%$ & $91.8 \%$ & $75.9 \%$ & $88.9 \%$ & $89.8 \%$ & $86.9 \%$ \\
\hline Sensitivity & $82.5 \%$ & $85.4 \%$ & $71.1 \%$ & $62.5 \%$ & $65.1 \%$ & $48.0 \%$ & $65.6 \%$ & $75.1 \%$ & $60.9 \%$ & $50.6 \%$ \\
\hline Specificity & $80.2 \%$ & $88.8 \%$ & $84.4 \%$ & $87.1 \%$ & $92.4 \%$ & $95.6 \%$ & $81.4 \%$ & $92.8 \%$ & $94.1 \%$ & $92.4 \%$ \\
\hline $\begin{array}{l}\text { Fisher exact test: } \\
\text { 1-tailed } p\end{array}$ & 0.0001 & 0.0001 & 0.0001 & 0.0001 & 0.0001 & 0.0001 & 0.0001 & 0.0001 & 0.0001 & 0.0001 \\
\hline
\end{tabular}


The final model for each species contained between 5 and 9 variables with concordant pairs of 79.1 to $93 \%$ for Data Set A, and between 5 and 12 variables with concordant pairs of 85.3 to $94.0 \%$ for Data Set B (Table 2). The explained deviance between the intercept-only model and the intercept+covariates model varied between 18.2 and $48.5 \%$ and between 29.0 and $52.5 \%$ for Data Sets A and B respectively. All final models were highly significant, with p-values at 0.0001 for both data sets. The sensitivity and specificity were moderate to high for most species, the sensitivity being higher in most cases for the data set with sediment characteristics.

Final models for each species appeared quite stable, as 10 model runs (based on the random selections of $50 \%$ of the data) on randomly generated sets of abiotic conditions generated highly correlated predictions (Table 3). All linear correlation coefficients between pairs of models were in the range of 0.89 to 0.99 for each species. Also the percentage of concordant pairs, percentage correctly predicted, sensitivity and specificity did not change much as a function of which random set of $50 \%$ of the data was used to build the model (Table 3a) and test the model (Table 3b). The standard deviations of these diagnostics were low, suggesting that the models were not very dependent on any particular set of observations.

Maps of the probability of occurrence of the macrobenthic species appeared to be fairly consistent with the observations of presence and absence in the Schelde estuary, as shown in Figs 7 to 10 for Macoma balthica, Cerastoderma edule, Corophium volutator and Nephtys cirrosa respectively. $M$. balthica was observed along the complete salinity gradient, mainly in the intertidal zone, and the highest probabilities of occurrence coincided with this distribution. This was also observed for $C$. edule and $C$. volutator, 2 species with a mainly polyhaline, intertidal distribution and a mainly mesohaline, intertidal distribution respectively. C. edule showed a low probability of occurrence in the $\alpha$ mesohaline zone, and C. volutator a low probability of occurrence in the polyhaline zone of the estuary. N. cirrosa was a relatively common species in the subtidal polyhaline zone of the Schelde estuary, penetrating the estuary up to the $\alpha$-mesohaline zone. The model predicted a much broader distribution for this species, as was observed from the high probabilities of occurrence at almost all sampling locations in the subtidal polyhaline zone. Upstream of the polyhaline zone the model indicated a decreasing probability of occurrence.

Table 3. Summary of classification diagnostics for $50 \%$ of data (based on Data Set A, $\mathrm{n}=2827$ ) used to build models; $50 \%$ of data was resampled 10 times to create 10 sets of data to build models (a) and 10 sets of data to test models (b). Standard deviation is in parentheses. Consistency of the 10 model runs (a) for each species was tested on random sets of abiotic conditions, by generating 1000 uniformly distributed random numbers. The generated predicted p-values for the 10 model runs were compared mutually and the range of the linear correlation coefficients between all pairs is presented

\begin{tabular}{|c|c|c|c|c|c|c|}
\hline Species & $\begin{array}{l}\text { Correlation between } \\
10 \text { model runs }\end{array}$ & $\begin{array}{l}\text { n Mean } \\
\text { concordance }\end{array}$ & $\begin{array}{c}\text { Threshold } \\
\text { p }\end{array}$ & $\begin{array}{l}\% \text { correctly } \\
\text { predicted }\end{array}$ & Sensitivity & Specificity \\
\hline \multicolumn{7}{|l|}{ (a) Model-fitting data } \\
\hline Heteromastus filiformis & $0.976-0.999$ & $82.4(0.75)$ & $0.50(0.015)$ & $75.5(0.69)$ & $70.0(1.28)$ & $79.3(0.68)$ \\
\hline Macoma balthica & $0.968-0.998$ & $91.2(0.56)$ & $0.59(0.014)$ & $85.9(0.54)$ & $75.4(1.55)$ & $90.1(0.42)$ \\
\hline Pygospio elegans & $0.889-0.998$ & $90.5(0.78)$ & $0.50(0.010)$ & $86.3(0.76)$ & $74.9(1.77)$ & $90.6(0.56)$ \\
\hline Bathyporeia sp. & $0.979-0.999$ & $79.2(0.91)$ & $0.38(0.011)$ & $77.7(0.97)$ & $47.2(2.53)$ & $85.9(0.66)$ \\
\hline Cerastoderma edule & $0.895-0.991$ & $92.8(0.41)$ & $0.41(0.020)$ & $89.9(0.90)$ & $59.1(2.73)$ & $94.2(0.54)$ \\
\hline Nephtys cirrosa & $0.889-0.996$ & $82.4(0.70)$ & $0.32(0.018)$ & $84.1(0.80)$ & $34.3(2.11)$ & $91.0(0.51)$ \\
\hline Nereis diversicolor & $0.958-0.998$ & $93.0(0.43)$ & $0.43(0.012)$ & $87.7(0.88)$ & $66.0(4.63)$ & $92.7(0.49)$ \\
\hline Corophium volutator & $0.963-0.999$ & $92.3(0.76)$ & $0.33(0.012)$ & $90.3(1.18)$ & $64.5(2.08)$ & $94.2(1.32)$ \\
\hline Spio sp. & $0.973-0.999$ & $83.5(1.08)$ & $0.29(0.015)$ & $87.4(0.90)$ & $42.1(3.10)$ & $93.0(0.53)$ \\
\hline Arenicola marina & $0.889-0.994$ & $88.6(0.35)$ & $0.35(0.017)$ & $89.2(0.77)$ & $43.1(3.91)$ & $94.1(0.49)$ \\
\hline \multicolumn{7}{|l|}{ (b) Model-testing data } \\
\hline Heteromastus filiformis & & & $0.50(0.022)$ & $75.3(1.48)$ & $70.2(1.86)$ & $78.9(1.38)$ \\
\hline Macoma balthica & & & $0.61(0.022)$ & $95.0(0.41)$ & $74.4(1.15)$ & $89.4(0.42)$ \\
\hline Pygospio elegans & & & $0.52(0.024)$ & $86.4(0.64)$ & $74.9(1.69)$ & $90.6(0.45)$ \\
\hline Bathyporeia sp. & & & $0.39(0.020)$ & $78.6(0.83)$ & $46.8(2.58)$ & $86.6(0.56)$ \\
\hline Cerastoderma edule & & & $0.41(0.020)$ & $89.9(0.87)$ & $59.7(2.74)$ & $94.3(0.53)$ \\
\hline Nephtys cirrosa & & & $0.33(0.026)$ & $85.1(0.73)$ & $30.2(2.02)$ & $91.6(0.46)$ \\
\hline Nereis diversicolor & & & $0.42(0.024)$ & $87.9(0.86)$ & $69.6(2.01)$ & $92.5(0.72)$ \\
\hline Corophium volutator & & & $0.34(0.032)$ & $90.4(0.57)$ & $67.2(2.43)$ & $94.4(0.34)$ \\
\hline Spio sp. & & & $0.29(0.024)$ & $88.7(0.69)$ & $42.3(2.44)$ & $93.7(0.41)$ \\
\hline Arenicola marina & & & $0.35(0.030)$ & $89.1(0.78)$ & $42.4(4.84)$ & $94.0(0.45)$ \\
\hline
\end{tabular}




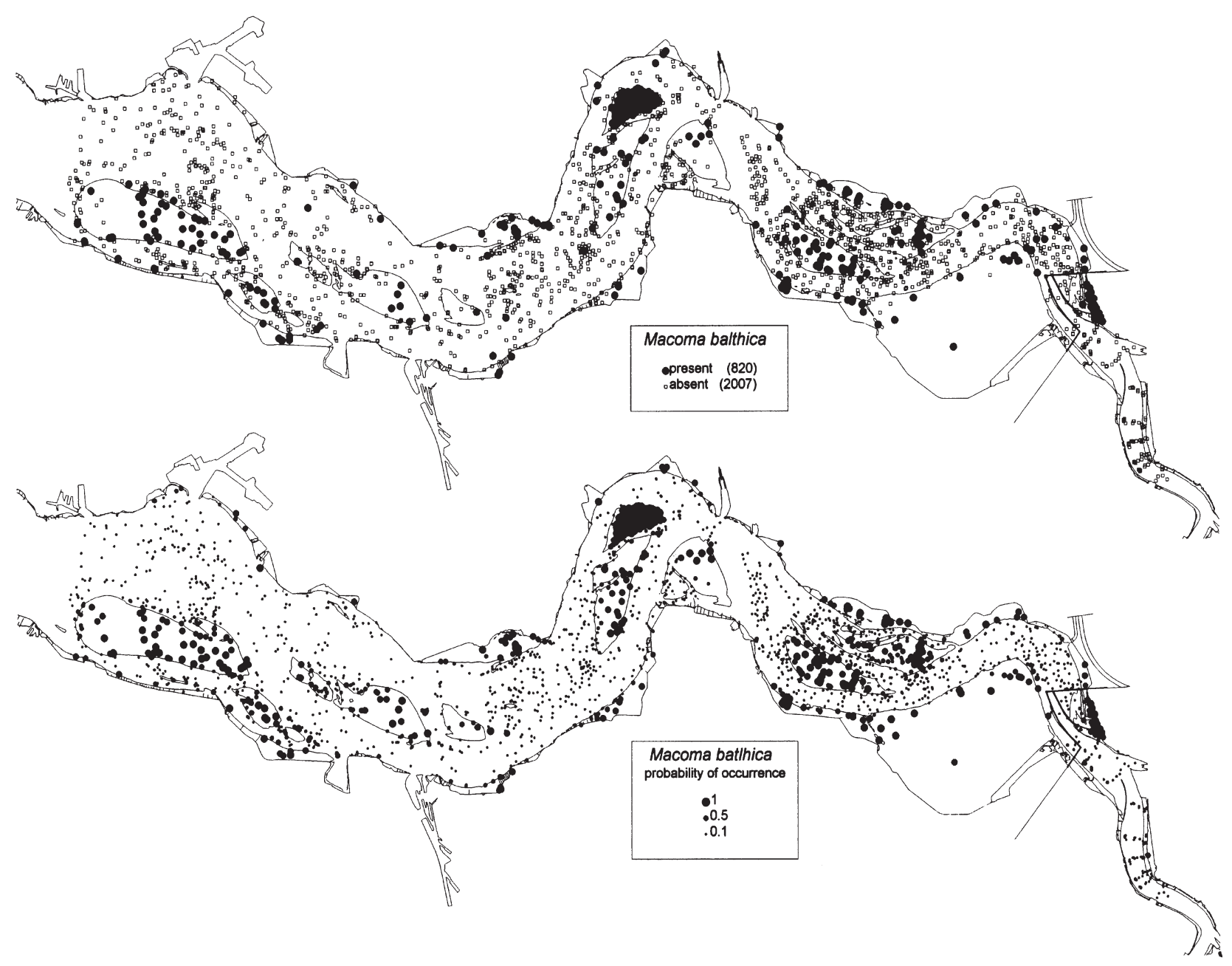

Fig. 7. Observed distribution (presence/absence) of Macoma balthica (top graph) and distribution of the determined probabilities of species occurrence based on multiple logistic regression model without sediment data (bottom graph). Probabilities of occurrence $(p)$ are shown on a graduated scale

\section{DISCUSSION}

In a review on the ecology of benthic macro-invertebrates in soft-sediment environment, Constable (1999) stated that the established need for developing statistical models and rigorous experimental designs has not penetrated far into the soft-substratum ecological literature. In this study, we statistically modelled and predicted the distribution (presence/absence) of individual macrobenthic species at scales relevant to management, based on small-scale core-sample information and environmental habitat variables including salinity, depth, currents (flow) and sediment composition.

Our model approach gave environmental response surfaces for individual macrobenthic species based on several known deterministic abiotic environmental variables (salinity, depth/elevation, tidal currents and sediment characteristics) which act at different spatial scales. Salinity obviously is a major determining factor of species distributions in estuaries (Boesch 1977, Dittmer 1983, Michaelis 1983, Wolff 1983, Mannino \& Montagna 1997, Ysebaert et al. 1998), and will determine the large-scale, longitudinal distributions. By including 'temporal salinity', we also built in the possible role of seasonal variation in salinity in explaining species distribution (e.g. Holland et al. 1987). Depth/ elevation, especially when considering the full range from the deep subtidal zone to the high intertidal zone, has a pronounced effect on the macrofauna species distribution along the vertical gradient within estuaries (Craeymeersch 1999, Ysebaert \& Meire 1999, Ysebaert 2000). Related to depth are tidal currents, which are generally stronger in the subtidal than in the intertidal 


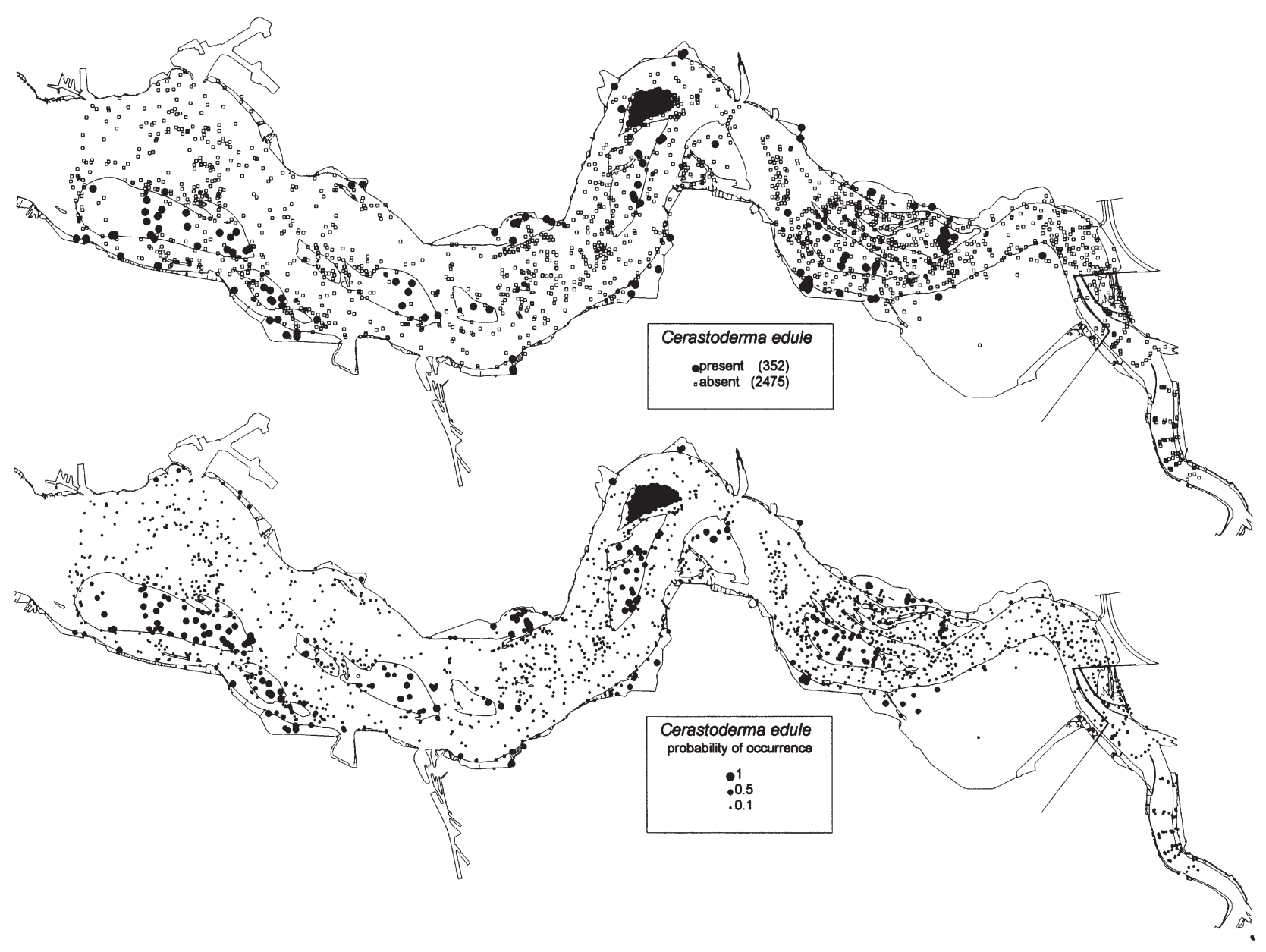

Fig. 8. The observed distribution (presence/absence) of Cerastoderma edule (top graph) and the distribution of the determined probabilities of species occurrence based on the multiple logistic regression model without sediment data (bottom graph). Probabilities of occurrence (p) are shown on a graduated scale

zone. Interactions of macrobenthic communities with their environment have traditionally been considered in the context of 'static' physical factors such as sediment characteristics and tidal inundation or exposure time, which are in turn determined largely by hydrodynamic processes (Warwick \& Uncles 1980, Nowell \& Jumars 1984, Warwick et al. 1991, Hall 1994). The importance of hydrodynamic variables such as current velocity, bed shear stress and wind-wave activity have also been recognised as influencing larval settlement and post-settlement transport (Grant 1983, Butman 1987, Commito et al. 1995), availability of particulate food resources (Miller et al. 1992, Wildish \& Kristmanson 1997) and the stability of the substratum (Warwick et al. 1991, Bell et al. 1997, Grant et al. 1997). At the local (smaller) spatial scale, sediment composition has been shown to influence estuarine benthic assemblage structure and species distribution (Gray 1974, Beu- kema 1976, Junoy \& Viétez 1990, Warwick et al. 1991, Meire et al. 1994).

These abiotic environmental variables (salinity, depth, maximum ebb- and flood-current velocities, median grain size and mud content) were used to statistically model and predict, through logistic regression, the distribution (presence/absence) of individual estuarine macrobenthic species at the estuarine macro- and meso-scale. Logistic regression has been applied in many ecological studies, but in the field of marine and estuarine animal ecology this technique has barely been used. On a univariate level, the obtained response curves as a function of the different abiotic environmental variables were in general agreement with the descriptive statistics on the occurrence of the different species along these gradients and are in general agreement with findings in the literature (see also Ysebaert \& Meire 1999). 


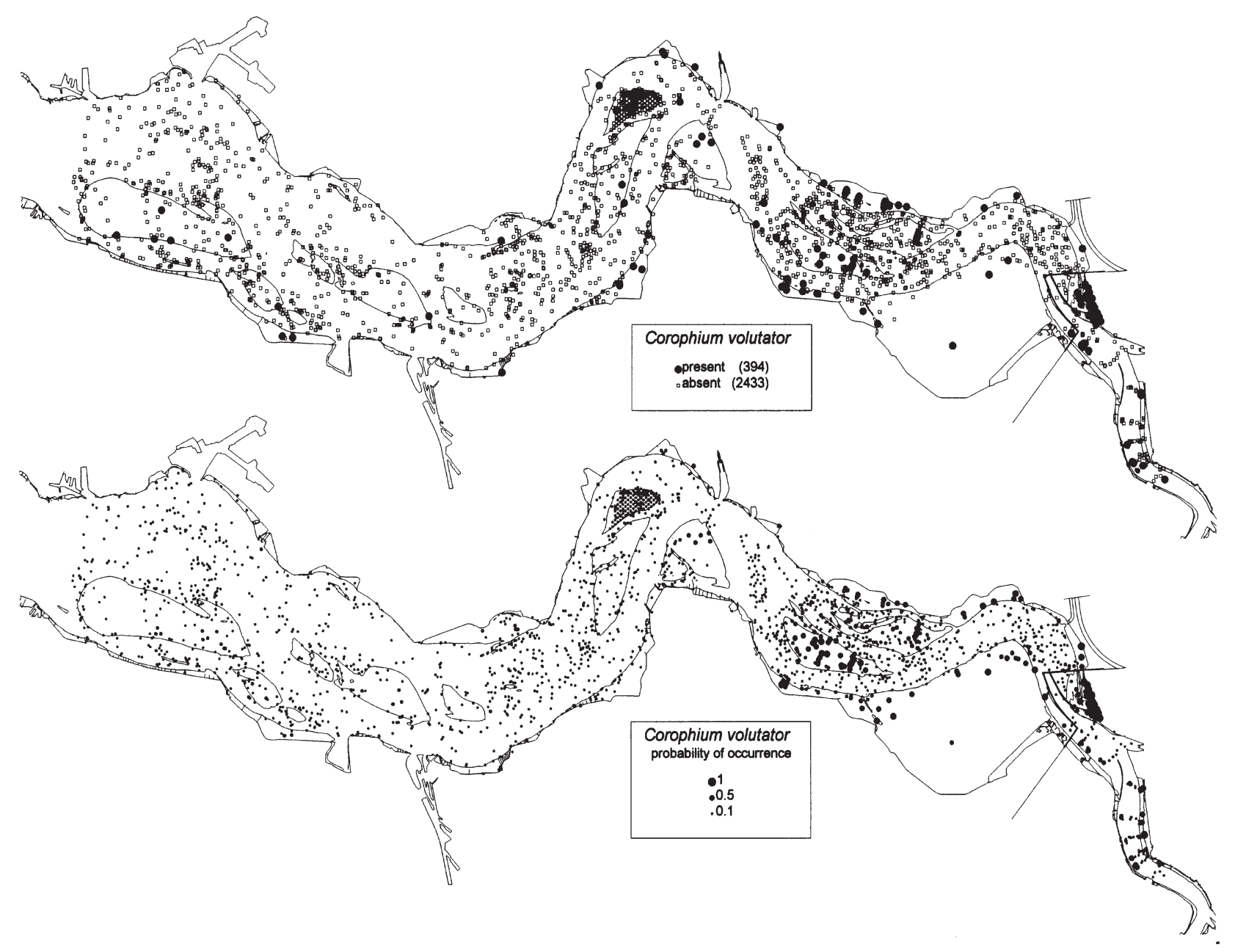

Fig. 9. Observed distribution (presence/absence) of Corophium volutator (top graph) and the distribution of the determined probabilities of occurrence based on the multiple logistic regression model without sediment data (bottom graph). Probabilities of occurrence $(p)$ are shown on a graduated scale

In most of our multivariate models, 1 or more estimates of salinity, depth, current velocity and sediment characteristics (for the models with sediment data) are entered into the models. This multivariate modelling approach allows incorporation of heterogeneity both within and across scales. Several of the environmental variables included in this analysis are correlated (see also Ysebaert 2000). As an example, depth is highly correlated with current velocities and, to a lesser extent, with sediment characteristics. Many pairs of mutually correlated variables were nevertheless included in the stepwise procedure in the same model. This is probably due to the fact that these correlations were not spatially consistent. When examined at different scales, the correlation between 2 variables may change. Therefore, when 1 variable is entered into the model, a second variable that is on average correlated with the first may still explain variation in the probability of occurrence.

In our model approach we used environmental variables as predictors for the distribution of macrobenthic species. An alternative, but not mutually exclusive viewpoint is that distributions are controlled more directly by biotic interactions, such as predation and inter- and intraspecific competition (Wilson 1991, Olafsson et al. 1994). The relative importance of processes determining the spatial distribution of macrofaunal species may depend on the scale considered. Biologically-generated patterns tend to be more important at the micro-scale $(<1 \mathrm{~m})$ but are less likely to appear at the macro- or meso-scale (Legendre et al. 1997, Thrush et al. 1997). However, relatively large-scale patterns generated by biological interactions have also been described. The lugworm Arenicola marina influences 


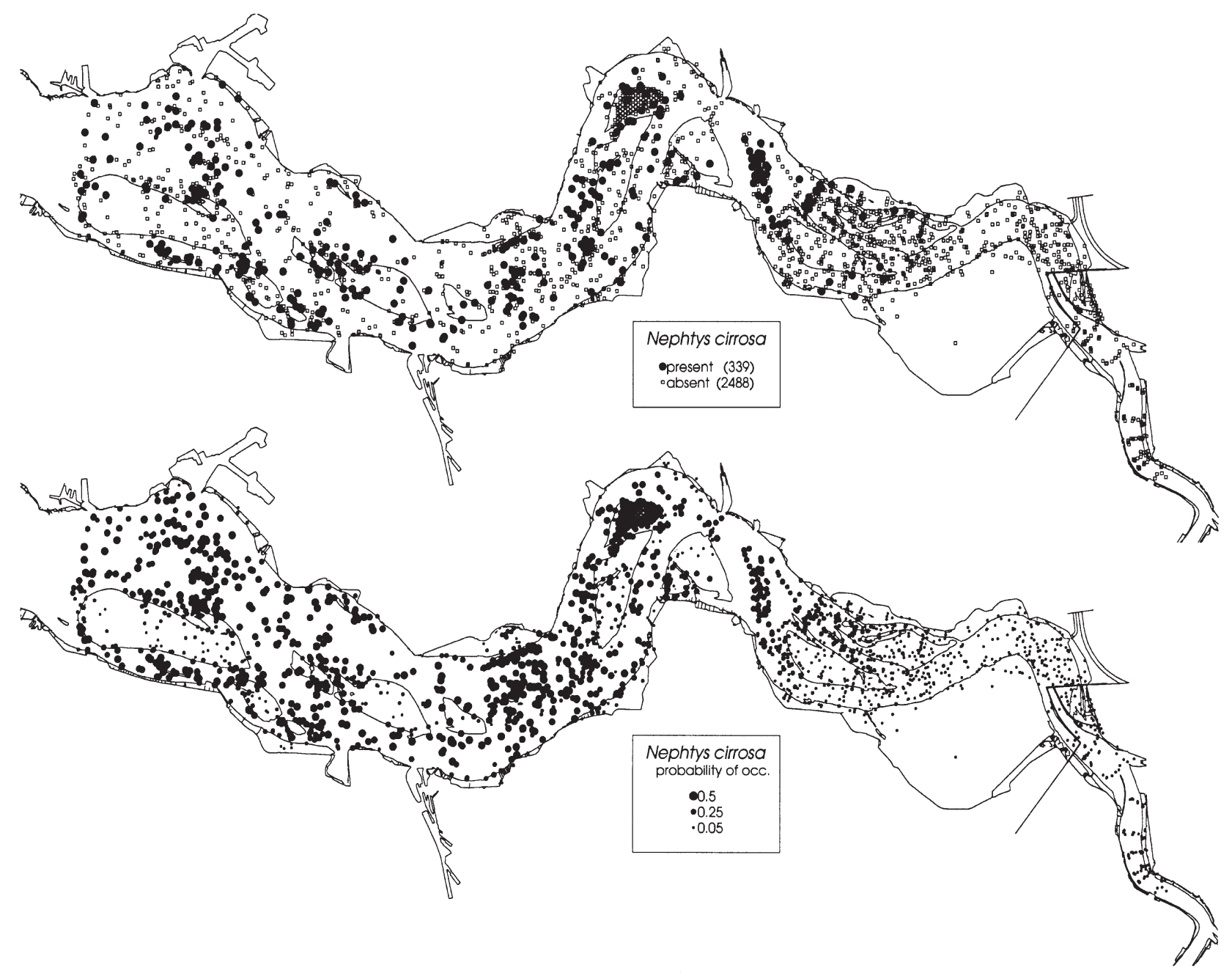

Fig. 10. Observed distribution (presence/absence) of Nephtys cirrosa (top graph) and distribution of the determined probabilities of occurrence based on the multiple logistic regression model without sediment data (bottom graph). Probabilities of occurrence (p) are shown on a graduated scale

the distribution of many other species by its bioturbating activities, e.g. the polychaete Pygospio elegans (Reise 1985), the amphipod Corophium volutator (Flach 1992), the seagrass Zoltera noltii (Philippart 1994). It is likely, in such cases, that the environmental factors determining the distribution of the superior competitor will be indirectly reflected in the response functions for the expelled species, falsely suggesting a direct dependence on abiotic factors where in fact a biologically-mediated dependence may be the case. Similar arguments may be valid with respect to the possibilities for settlement of some species. If the abiotic conditions at a particular place are within the tolerance limits of the adults, but conditions are adverse for settlement of juveniles, this may lead to absence of the species. In addition, different abiotic factors control the spatial distribution of adults and juveniles of sev- eral species (e.g. Legendre et al. 1997). In the Schelde estuary too there is evidence of such a difference. For instance, in the eastern (mesohaline) part of the estuary juvenile Cerastoderma edule was able to settle during summer but did not survive winter (and therefore did not mature) because of low salinity at that time (Ysebaert 2000). It would therefore be useful to analyse adult and juvenile stages separately, but unfortunately data on life stages were not always available in our data set.

In summary, therefore, the patterns described by the response curves should not be interpreted as descriptions of the physiological limits of the species or of the adults in the species, but as descriptions of actual distribution patterns as a function of abiotic variables, whatever the direct or indirect dependence on these variables may be. 
Quantifying the associations between the probability of occurrence of estuarine macrobenthic species and abiotic environmental variables allows us to generate predictions of distribution, which may be robust even if the mechanisms or processes are not known. Indeed, the type of pattern analysis conducted in this study does not allow any direct conclusions to be drawn on the processes that determine macrobenthic species distribution. Nevertheless, pattern analysis and modelling are critical steps in ecological research and resource management (Thrush et al. 1999). Where patterns of distribution are strongly and directly coupled to physicochemical processes, as is the case at the estuarine macro- and meso-scales, our modelling approach was capable of predicting macrobenthic species distributions with a relatively high degree of success.

We are able to predict the probability of occurrence for some species better than for others. This variability in success may have different causes. It is difficult to ascertain that all (or most) of the relevant factors for the distribution of a species have been taken into account. Statistical approaches such as that followed here depend on the ability to assemble sufficient environmental information at all sampling points. Potentially important factors related to food availability (e.g. biomass and productivity of microphytobenthos [Herman et al. 2000] and productivity of the phytoplankton [Herman et al. 1999]) have not been taken into account. Likewise, we have restricted our analyses here to single species, excluding possible strong interactions between different macrobenthic populations. The spatial resolution for most abiotic variables used was very high, but may still have been insufficient, especially at the edges of the intertidal flats. Strong gradients in height, current velocities and sediment composition may occur at these edges, and this may be a reason for the relatively high percentage of prediction failures at these edges. Moreover, intertidal flats are mobile over time, and we have imposed a fixed bathymetry and current patterns onto a biological data set gathered over a 10 yr period. From sampling practice, we know that some edges of tidal flats may move tens or even hundreds of meters in a few years. Although preliminary trend-analyses did not reveal strong evolutions of the biological communities over the past $10 \mathrm{yr}$, some trends could also have gone unnoticed and caused additional unexplained variation. Finally, our analysis has not taken into account the small-scale spatial structure of macrobenthic populations. Due to patchiness of the populations, and the size of the sampling units, a zero observation (species absent) can have quite different meanings: either the species is really absent from the zone sampled, or is immediately adjacent but missed by the sampling.
Such effects are predictably variable between species. Rare, large or very clumped populations are expected to have more 'false zeros' then abundant, small and homogeneously distributed populations. Correction of the estimation methods for these effects would require a thorough investigation of small-scale distributions of the different species, which could potentially lead to an improvement of the prediction success. Identifying patterns at various spatial scales may also provide a clue as to the kinds of processes that operate at that particular scale (Thrush et al. 1999).

The next step will be to investigate the possibility of using the models and predictions for evaluation of the effects of different management schemes (e.g. a further deepening of the shipping channel) within the Schelde estuary. This requires an evaluation of the robustness of the models to different states of the system. The most appropriate test for this robustness is to investigate the applicability of the models to other estuarine systems. Inclusion of process information (especially on the feeding habits of the macrobenthic species) and natural history information will certainly improve the quality and generality of the models by making the predictions more robust to changes in physico-chemical forcing of the system and, in the long-term, will allow the development of models describing the action and interaction of processes operating at different scales (Allen \& Starr 1982, Wiens 1982, Thrush 1991, Schneider 1994, Thrush et al. 1999).

Acknowledgements. We thank all the people involved in taking and sorting the samples that made up our database. In particular we thank Johan Craeymeersch and John Buijs who were responsible for much of the sampling and for setting up large parts of the database. The help of Marijn van Helvert was needed for the hydrodynamical simulations. We thank Greet De Gueldre for comments on the manuscript. This study was part of the ECOFLAT project, a research project funded by the European Commission in the framework of ENVIRONMENT \& CLIMATE Programme (contract number ENV4-CT96-0216), being part of ELOISE (European Land Ocean Interactions Studies). This is Contribution 220 to the EU programme ELOISE and Contribution 2788 of the Netherlands Institute of Ecology.

\section{LITERATURE CITED}

Allen TFH, Starr TB (1982) Hierarchy: perspectives for ecological complexity. University of Chicago Press, Chicago Aller RC, Aller JY (1998) The effect of biogenic irrigation intensity and solute exchange on diagenetic reaction rates in marine sediments. J Mar Res 56:905-936

Austin MP (1987) Models for the analysis of species response to environmental gradients. Vegetatio 69:35-45

Baeyens W, van Eck B, Lambert C, Wollast R, Goeyens L (1998) General description of the Scheldt estuary. Hydrobiologia 366:1-14 
Appendix 1.

\begin{tabular}{|c|c|c|c|c|c|c|c|}
\hline \multicolumn{4}{|c|}{ Heteromastus filiformis } & \multicolumn{2}{|c|}{ Macoma balthica } & & \\
\hline Intercept & -2.2298 & Intercept & -7.5618 & Intercept & 0.4229 & Intercept & 0.6798 \\
\hline Max. flood & removed & Max. flood & -2.9286 & Max. flood & 3.5401 & Median $^{2}$ & -0.00006 \\
\hline Max. ebb ${ }^{2}$ & -0.7335 & Depth & -0.2340 & Depth & -0.4422 & Depth & removed \\
\hline Temp. sal. $^{2}$ & -0.00426 & Median & -0.00552 & Depth $^{2}$ & 0.00823 & Model sal. & -0.3009 \\
\hline Temp. sal. & 0.1147 & Model sal. & 0.4851 & Max. flood ${ }^{2}$ & -5.8467 & Max. flood ${ }^{2}$ & -10.5546 \\
\hline Model sal. & 0.3433 & Model sal. ${ }^{2}$ & -0.00845 & Max. ebb ${ }^{2}$ & -4.7585 & Temp. sal ${ }^{2}$ & -0.0159 \\
\hline Model sal. $^{2}$ & -0.00845 & Mud & 0.1073 & Max. ebb & 3.6948 & Temp. sal & 0.3963 \\
\hline Max. flood $^{2}$ & -1.7250 & $\mathrm{Mud}^{2}$ & -0.00114 & & & Model sal. ${ }^{2}$ & 0.0140 \\
\hline Depth $^{2}$ & 0.00448 & Max. flood ${ }^{2}$ & removed & & & Depth $^{2}$ & -0.0980 \\
\hline \multirow{6}{*}{ Depth } & -0.1261 & Temp. sal ${ }^{2}$ & -0.0129 & & & & \\
\hline & & Temp. sal & 0.3599 & \multicolumn{2}{|c|}{ Pygospio elegans } & & \\
\hline & & Depth $^{2}$ & 0.00732 & Intercept & -5.2640 & Intercept & -7.5609 \\
\hline & & Max. ebb & 7.7127 & Max. flood & removed & Max. flood & -3.1578 \\
\hline & & Max. ebb² & -4.9373 & Depth & -0.3914 & Model sal. & 0.9682 \\
\hline & & & & Depth $^{2}$ & 0.0103 & Model sal. $^{2}$ & -0.0213 \\
\hline \multicolumn{2}{|c|}{ Nereis diversicolor } & & & Model sal. & 0.6872 & Median $^{2}$ & -0.00006 \\
\hline Intercept & 7.3822 & Intercept & 9.0758 & Model sal. ${ }^{2}$ & -0.0156 & Depth & -0.4163 \\
\hline Max. flood & -1.1788 & Max. ebb & -3.8073 & Max. ebb ${ }^{2}$ & -1.0291 & Depth $^{2}$ & 0.0125 \\
\hline Depth & -0.6146 & Median & -0.00954 & Max. flood ${ }^{2}$ & -2.3810 & Median & 0.0102 \\
\hline Depth $^{2}$ & 0.0106 & Depth & -0.6606 & & & & \\
\hline Model sal. & -0.4199 & Depth $^{2}$ & 0.0197 & \multicolumn{2}{|c|}{ Bathyporeia sp. } & & \\
\hline Max. ebb & -2.8955 & Model sal. & -0.0878 & Intercept & -7.2309 & Intercept & -2.6535 \\
\hline \multirow{5}{*}{ Model sal. $^{2}$} & 0.00871 & Model sal. ${ }^{2}$ & removed & Depth & -0.2882 & Mud & -0.0978 \\
\hline & & $\mathrm{Mud}^{2}$ & -0.00024 & Temp. sal. ${ }^{2}$ & -0.00626 & Depth & -0.4620 \\
\hline & & Temp. sal & -0.3703 & Temp. sal. & 0.1585 & Depth$^{2}$ & 0.0126 \\
\hline & & Temp. sal $^{2}$ & 0.0105 & Max. ebb ${ }^{2}$ & 1.1721 & Max. ebb & 4.1235 \\
\hline & & & & Depth $^{2}$ & 0.00571 & Temp. sal ${ }^{2}$ & -0.0125 \\
\hline \multicolumn{3}{|c|}{ Corophium volutator } & & Model sal. & 0.6689 & Temp. sal & 0.3857 \\
\hline Intercept & 6.6438 & Intercept & 6.2743 & Model sal. ${ }^{2}$ & -0.0169 & Max. ebb ${ }^{2}$ & -1.7495 \\
\hline Model sal. & -0.4245 & Median & -0.0111 & & & & \\
\hline Max. ebb & -3.2311 & Max. ebb & -3.3653 & \multicolumn{2}{|l|}{ Spio sp. } & & \\
\hline Depth & -0.4134 & Model sal. & -0.1884 & Intercept & -16.9542 & Intercept & -17.1183 \\
\hline Depth $^{2}$ & 0.00755 & Depth & -0.4738 & \multicolumn{2}{|c|}{ Temp. sal. ${ }^{2}$ removed } & Temp. sal. & 1.1932 \\
\hline \multirow[t]{2}{*}{ Model sal. ${ }^{2}$} & 0.00582 & Depth $^{2}$ & 0.0145 & Temp. sal. & 0.3402 & Model sal. $^{2}$ & -0.00635 \\
\hline & & & & Model sal. $^{2}$ & -0.0204 & Max. flood & 6.0268 \\
\hline Nepthys cir & & & & Model sal. & 0.7173 & Max. flood ${ }^{2}$ & -2.7218 \\
\hline Intercept & -19.6625 & Intercept & -13.8353 & Max. ebb ${ }^{2}$ & -0.5283 & Temp. sal ${ }^{2}$ & -0.0151 \\
\hline Temp. sal & 0.7573 & Depth & 0.5568 & Max. ebb & oved & Median $^{2}$ & -0.00003 \\
\hline Max. ebb & 7.4088 & Temp. sal. & 0.8223 & Max. flood & 8.0842 & Mud & -0.1292 \\
\hline Temp. sal. $^{2}$ & -0.0151 & Depth $^{2}$ & -0.0181 & Max. flood ${ }^{2}$ & -5.1461 & $\mathrm{Mud}^{2}$ & 0.00146 \\
\hline Max. ebb ${ }^{2}$ & -3.6803 & Temp. sal ${ }^{2}$ & -0.0154 & & & & \\
\hline Model sal. & 0.4195 & Mud & -0.1074 & Arenicola m & & & \\
\hline Model sal. $^{2}$ & -0.00728 & Max. ebb ${ }^{2}$ & -0.8913 & Intercept & -13.4934 & Intercept & -9.3460 \\
\hline & & & & Max. flood & -1.9627 & Model sal. & 0.2921 \\
\hline Cerastoder & & & & Model sal. & 1.0284 & Max. flood & -3.3583 \\
\hline Intercept & -13.2667 & Intercept & -11.5229 & Model sal. ${ }^{2}$ & -0.0194 & Temp. sal. $^{2}$ & -0.00260 \\
\hline Max. flood & removed & Max. flood & -4.0737 & Depth & -0.2633 & Depth & 1.4338 \\
\hline Model sal. & 0.6427 & Model sal. & 0.6943 & Max. ebb ${ }^{2}$ & -6.6295 & Depth $^{2}$ & -0.3155 \\
\hline Depth & -0.3871 & Median $^{2}$ & -0.00004 & Max. ebb & 5.4847 & Max. ebb & 3.0047 \\
\hline Model sal. ${ }^{2}$ & -0.0129 & Model sal. $^{2}$ & -0.0114 & Depth$^{2}$ & 0.00438 & Median $^{2}$ & -0.00007 \\
\hline Temp. sal. & 0.2972 & Temp. sal & 0.4338 & Temp. sal. $^{2}$ & -0.00099 & Median & 0.0208 \\
\hline Max. flood $^{2}$ & -4.0479 & Depth & -0.1868 & & & & \\
\hline Depth $^{2}$ & 0.00696 & Temp. sal. ${ }^{2}$ & -0.0103 & & & & \\
\hline Max. ebb ${ }^{2}$ & -18.4287 & & & & & & \\
\hline Max. ebb & 14.7480 & & & & & & \\
\hline Temp. sal. $^{2}$ & -0.00503 & & & & & & \\
\hline
\end{tabular}


Bell RG, Hume TM, Dolphin TJ, Green MO, Walters RA (1997) Characterisation of physical environmental factors on an intertidal sandflat, Manukau Harbour, New Zealand. J Exp Mar Biol Ecol 216:11-31

Beukema JJ (1976) Biomass and species richness of the macrobenthic animals living on tidal flats of the Dutch Wadden-sea. Neth J Sea Res 10:236-261

Bio AMF, Alkemade R, Barendregt A (1998) Determining alternative models for vegetation response analysis: a non-parametric approach. J Veg Sci 9:5-16

Boesch DF (1977) A new look at the zonation of benthos along the estuarine gradient. In: Coull BC (ed) Ecology of marine benthos. Vol. 6. The Belle W. Baruch Library in Marine Science. University of South Carolina Press, Columbia, SC, p 245-266

Boesch DF, Rosenberg R (1981) Response to stress in marine benthic communities. In: Barrett GW, Rosenberg R (eds) Stress effects on natural ecosystems. John Wiley, New York, p 179-200

Brummelhuis E B M, Craeymeersch JA, Markusse R, Sistermans W (1997) The macrobenthos of Westerschelde, Oosterschelde, Veerse meer and Grevelingenmeer in autumn 1996. Report Biologisch Monitoring Programma. Netherlands Institute of Ecology, Yerseke (in Dutch)

Buckland ST, Elston DA (1993) Empirical models for the spatial distribution of wildlife. J Appl Ecol 30:478-495

Butman CA (1987) Larval settlement of soft-sediment invertebrates: the spatial scales of pattern explained by active habitat selection and the emerging role of hydrodynamical processes. Oceanogr Mar Biol Annu Rev 25: 113-165

Constable AJ (1999) Ecology of benthic macro-invertebrates in soft-sediment environments: a review of progress towards quantitative models and predictions. Aust J Ecol 24:452-476

Cox DR (1970) The analysis of binary data. Methuen, London

Commito JA, Thrush SF, Pridmore RD, Hewitt JE, Cummings VJ (1995) Dispersal dynamics in a wind-driven benthic system. Limnol Oceanogr 40:1513-1518

Craeymeersch J (1999) The use of macrobenthic communities in the evaluation of environmental change. $\mathrm{PhD}$ thesis, University of Ghent

Craeymeersch JA, Brummelhuis EBM, Dimmers M, Markusse R, Sistermans W (1996) The macrobenthos of Westerschelde, Oosterschelde, Veerse meer and Grevelingenmeer in autumn 1995. Report Biologisch Monitoring Programma. Netherlands Institute of Ecology, Yerseke (in Dutch)

Day JW Jr, Hall AS, Kemp WM, Yanez-Arancibia A (1989) Estuarine ecology. John Wiley, New York

Dekker L, Lievense P, van der Male C (1994) Calibratie en verificatie SCALDIS100. Rijkswaterstaat, Rijksinstituut voor Kust en Zee, Middelburg (werkdocument RIKZ/AB94.839x)

Dittmer JD (1983) The distribution of subtidal macrobenthos in the estuaries of the rivers Ems and Weser. In Wolff W (ed) Ecology of the Wadden Sea. Vol. I. Balkema, Rotterdam, p 4/188-4/206

Flach EC (1992) The influence of four macrozoobenthic species on the abundance of the amphipod Corophium volutator on tidal flats of the Wadden Sea. Neth J Sea Res 29: 379-394

Gaston GR, Rakocinski CF, Brown SS, Cleveland CM (1998) Trophic function in estuaries: response of macrobenthos to natural and contaminant gradients. Mar Freshw Res 49: 833-846

Grant J (1983) The relative magnitude of biological and phys- ical sediment reworking in an intertidal community. J Mar Res 41:673-689

Grant J, Turner SJ, Legendre P, Hume TM, Bell RG (1997) Patterns of sediment reworking and transport over small spatial scales on an intertidal sandflat, Manukau Harbour, New Zealand. J Exp Mar Biol Ecol 216:33-50

Gray JS (1974) Animal-sediment relationships. Oceanogr Mar Biol Ann Rev 12:223-261

Hall SJ (1994) Physical disturbance and marine benthic communities: life in unconsolidated sediments. Oceanogr Mar Biol Ann Rev 32:179-239

Heip CHR, Herman PMJ (1995) Major biological processes in European tidal estuaries. Hydrobiologia 311

Heip CHR, Goosen NK, Herman PMJ, Kromkamp J, Middelburg JJ, Soetaert K (1995) Production and consumption of biological particles in temperate tidal estuaries. Oceanogr Mar Biol Ann Rev 33:1-150

Herman PMJ, Heip CHR (1999) Biogeochemistry of the Maximum Turbidity Zone of Estuaries (MATURE). J Mar Syst 22:89-228

Herman PMJ, Middelburg JJ, van de Koppel J, Heip CHR (1999) Ecology of estuarine macrobenthos. Adv Ecol Res 29:195-240

Herman, PMJ, Middelburg JJ, Widdows J, Lucas CH, Heip CHR (2000) Stable isotope labelling experiments confirm the importance of microphytobenthos as food for macrofauna. Mar Ecol Prog Ser 204:79-92

Holland AF, Shaughnessy AT, Hiegel MH (1987) Long-term variation in mesohaline Chesapeake Bay macrobenthos: spatial and temporal patterns. Estuaries 10:227-245

Hosmer DW, Lemeshow S (1989) Applied logistic regression. John Wiley, New York

Huisman J, Olff H, Fresco LFM (1993) A hierarchical set of models for species response analysis. J Veg Sci 4:37-46

Jongman RHG, ter Braak CJF, van Tongeren OFR (1995) Data analysis in community and landscape ecology, 2nd edn. Cambridge University Press, Cambridge

Junoy J, Viétez JM (1990) Macrozoobenthic community structure in the Ría de Foz, an intertidal estuary (Galicia, Northwest Spain). Mar Biol 107:329-339

Legendre P, Thrush SF, Cummings VJ, Dayton PK and 9 others (1997) Spatial structure of bivalves in a sandflat: scale and generating processes. J Exp Mar Biol Ecol 216: 99-128

Lenihan JM (1993) Ecological response surfaces for North American boreal tree species and their use in forest classification. J Veg Sci 4:667-680

Lievense P (1994) Waterbewegingsmodel SCALDIS400. Rijkswaterstaat, Directie Zeeland. Middelburg (rapport AX 94.072)

Mannino A, Montagna PA (1997) Small-scale spatial variation in macrobenthic community structure. Estuaries 20: 159-173

McCullagh P, Nelder JA (1989) Generalized linear models, 2nd edn. Chapman \& Hall, London

Meire P, Vincx M (1993) Marine and estuarine gradients. Proc 21st Symp Estuar Coast Sci Assoc. Neth J Aquat Ecol 27 : 71-489

Meire PM, Seys JJ, Ysebaert TJ, Coosen J (1991) A comparison of the macrobenthic distribution and community structure between two estuaries in SW Netherlands. In: Elliott M, Ducrotoy JP (eds) Estuaries and coasts: spatial and temporal intercomparisons. Olsen \& Olsen, Fredensborg, p 221-230

Meire PM, Seys J, Buijs J, Coosen J (1994) Spatial and temporal patterns of intertidal macrobenthic populations in the Oosterschelde: are they influenced by the construc- 
tion of the storm-surge barrier? Hydrobiologia 282/283: $157-182$

Michaelis H (1983) Intertidal benthic animal communities of the estuaries of the rivers Ems and Weser. In: Wolff WJ (ed) Ecology of the Wadden Sea. Vol. I. Balkema, Rotterdam, p 4/158-4/188

Miller DC, Bock MJ, Turner EJ (1992) Deposit and suspension feeding in oscillatory flows and sediment fluxes. J Mar Res 50:459-520

Nelder JA, Wedderburn RWM (1972) Generalized linear models. J Roy Stat Soc A135:370-384

Nowell ARM, PA Jumars (1984) Flow environments of aquatic benthos. Annu Rev Ecol Syst 15:303-328

Olafsson EB, Peterson CH, Ambrose WB (1994) Does recruitment limitation structure populations and communities of macroinvertebrates in marine soft sediment: the relative significance of pre- and post-settlement processes. Oceanogr Mar Biol Ann Rev 32:65-109

Osborne PE, Tigar BJ (1992) Interpreting bird atlas data using logistic models: an example from Lesotho, Southern Africa. J Appl Ecol 29:55-62

Pearson TH, Rosenberg R (1978) Macrobenthic succession in relation to organic enrichment and pollution of the marine environment. Oceanogr Mar Biol Ann Rev 16:229-311

Philippart CJM (1994) Interactions between Arenicola marina and Zostera noltii on a tidal flat in the Wadden Sea. Mar Ecol Prog Ser 111:251-257

Reise K (1985) Tidal flat ecology; an experimental approach to species interactions. Springer-Verlag, Berlin

Rhoads DC (1974) Organism-sediment relations on the muddy sea floor. Oceanogr Mar Biol Ann Rev 12:263-300

Schneider D (1994) Quantitative ecology: spatial and temporal scaling. Academic Press, New York

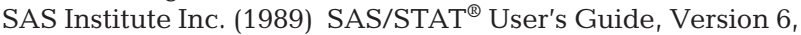
Forth Edition. SAS Institute Inc., Cary, NC

Soetaert K, Herman PMJ (1995) Estimating estuarine residence times in the Westerschelde (The Netherlands) using a box model with fixed dispersion coefficients. Hydrobiologia 311:215-224

Swan JMA (1970) An examination of some ordination problems by use of simulated vegetation data. Ecology 51: 89-102

ter Braak CJF, Looman CWN (1986) Weighted averaging, logistic regression and the Gaussian response model. Vegetatio 65:3-11

Thrush SF (1991) Spatial patterns in soft-bottom communities. Trends Ecol Evol 6:75-79

Thrush SF, Cummings VJ, Dayton PK, Ford R and 11 others (1997) Matching the outcome of small-scale density manipulation experiments with larger scale patterns: an example of bivalve adult/juvenile interactions. J Exp Mar Biol Ecol 216:153-169

Thrush SF, Lawrie SM, Hewitt JE, Cummings VJ (1999) The problem of scale: uncertainties and implications for softbottom marine communities and the assessment of human

Editorial responsibility: Otto Kinne (Editor),

Oldendorf/Luhe, Germany impacts. In: Gray JS, Ambrose W, Szaniawska A (eds) Biochemical cycling and sediment ecology. Kluwer Academic Publishers, The Netherlands, p 195-210

Trexler JC, Travis J (1993) Nontraditional regression analyses. Ecology 74:1629-1637

van de Rijt CWCJ, Hazelhoff L, Blom CWPM (1996) Vegetation zonation in a former tidal area: a vegetation-type response model based on DCA and logistic regression using GIS. J Veg Sci 7:505-518

Venier LA, McKenney DW, Wang Y, McKee J (1999) Models of large-scale breeding-bird distribution as a function of macro-climate in Ontario, Canada. J Biogeogr 26:315-328

Warwick RM (1986) A new method for detecting pollution effects on marine macrobenthic communities. Mar Biol 92: $557-562$

Warwick RM, Uncles RJ (1980) Distribution of benthic macrofauna associations in the Bristol Channel in relation to tidal stress. Mar Ecol Prog Ser 3:97-103

Warwick RM, Goss-Custard JD, Kirby R, George CL, Pope ND, Rowden AA (1991) Static and dynamic environmental factors determining the community structure of estuarine macrobenthos in SW Britain: why is the Severn estuary different? J Appl Ecol 28:329-345

Wiens JA (1989) Spatial scaling in ecology. Funct Ecol 3: 385-397

Wildish DJ, Kristmanson DD (1997) Benthic suspension feeders and flow. Cambridge University Press, Cambridge

Wilson WH (1991) Competition and predation in marine softsediment communities. Annu Rev Ecol Syst 21:221-241

Wolff WJ (1983) Estuarine benthos. In: Ketchum BH (ed) Ecosystems of the world Vol. 26. Estuaries and enclosed seas. Elsevier, Amsterdam, p 337-374

Ysebaert T (2000) Macrobenthos and waterbirds in the estuarine environment: spatio-temporal patterns at different scales. Communication 16. The Institute of Nature Conservation, Brussels

Ysebaert T, Meire P (1991) The macrobenthos of the Westerschelde and lower Zeeschelde. University of Ghent, Laboratory for Animal Ecology and Institute of Nature Conservation, Brussel, Belgium (Report IN A92.085) (in Dutch)

Ysebaert T, Meire P (1999) Macrobenthos of the Schelde estuary: predicting macrobenthic species responses in the estuarine environment. A statistical analysis of the Schelde estuary macrobenthos within the ECOFLAT project. Institute of Nature Conservation, Brussel, Belgium (Rep. No. IN 99.19)

Ysebaert T, Meire P, Maes D, Buijs J (1993) The benthic macrofauna along the estuarine gradient of the Schelde estuary. Neth J Aquat Ecol 27:327-341

Ysebaert T, Meire P, Coosen J, Essink K (1998) Zonation of intertidal macrobenthos on estuaries of Schelde and Ems. Aquat Ecol 32:53-71

Ysebaert T, de Neve L, Meire P (2000) The subtidal macrobenthos in the mesohaline part of the Schelde estuary (Belgium): influenced by man? J Mar Biol Assoc UK 80:587-597

Submitted: May 8, 2000; Accepted: March 15, 2001

Proofs received from author(s): October 26, 2001 